6

7

\title{
Glacitectonic composite ridge systems and surge-type glaciers: an updated correlation based on Svalbard, Norway
}

\author{
Harold Lovell* and Clare M. Boston \\ Department of Geography, University of Portsmouth, Lion Terrace, Portsmouth, PO1 3HE, \\ UK. *E-mail: harold.lovell@port.ac.uk; ORCID: 0000-0002-9435-3178
}

\begin{abstract}
Glacitectonic composite ridge systems are found at the margins of a number of surge-type glaciers globally. On the High-Arctic archipelago of Svalbard, the pioneering work of Croot (1988a) highlighted the coincidence between composite ridge systems and surge-type glaciers on the island of Spitsbergen. These observations have contributed significantly to our understanding of the links between glacier surges and the landforms they produce. We update this work and expand it to the whole archipelago by using the Norwegian Polar Institute's TopoSvalbard aerial photograph archive to identify 50 composite ridge systems. These are found on all four of the largest islands: Spitsbergen, Nordaustlandet, Edgeøya and Barentsøya, and at the margins of both tidewater and land-terminating glaciers. Of the 50 composite ridge systems, 49 are associated with glaciers that have either been documented as surge-type or contain indicative geomorphological evidence of surging in the form of crevasse-squeeze ridge (CSR) networks. This provides further support for the established link between composite ridge systems and surging. Based on the proportion of glaciers that are documented as being of surge type and those that display indicative evidence of surging (but have not been observed to surge), we conclude that at least $32.6 \%$ of all glaciers in Svalbard surge or are likely to have surged. This study contributes to the understanding of the links between glacier surging and specific landforms/landform assemblages (composite ridge systems and CSR networks), which has applications in other modern glacial environments and at the margins of former ice masses in palaeoglaciological settings.
\end{abstract}

KEY WORDS: composite ridge systems; surge-type glaciers; glacial geomorphology; glacitectonics; crevasse-squeeze ridges; Svalbard

\section{Acknowledgements}


This study would not have been possible without access to the Norwegian Polar Institute's

TopoSvalbard aerial photograph archive. We would like to thank Doug Benn, Sven Lukas and Wes Farnsworth for useful discussions on this topic, Derek Mottershead for commenting on an earlier version, and Richard Waller and an anonymous reviewer for making suggestions that have significantly improved the paper.

\section{Introduction}

Composite ridge systems are large (up to $100 \mathrm{~m}$ high), multi-crested glacitectonic depositional landforms composed of deformed unconsolidated sediment (cf. Aber et al. 1989) found at the margins of both modern glaciers (e.g. von Heuglin, 1872, Garwood and Gregory 1898; Lamplugh 1911; Gripp 1929; Kälin 1971; Croot 1988a, b; Hagen 1988; Evans and England 1991; Huddart and Hambrey 1995; Hart and Watts 1997; Boulton et al. 1996, 1999; van der Meer 2004; Benediktsson et al. 2008, 2009, 2010, 2015; Kristensen et al. 2009a, b; Roberts et al. 2009; Lønne 2016) and former ice sheets (e.g. Clayton et al. 1985; Aber et al. 1989; Hart 1990; van der Wateren 1995; Evans and Rea 1999; Evans et al. 1999, 2008; Benn and Clapperton 2000; Bakker and van der Meer 2003; Kehew et al. 2005; Boston et al. 2010; Darvill et al. 2016; Gribenski et al. 2016). The origin of composite ridge systems is typically attributed to proglacial and/or sub-marginal glacitectonic deformation during periods of sustained glacier/ice lobe advance as stresses are transmitted longitudinally through foreland sediments (e.g. Clayton et al. 1985; Aber et al., 1989; van der Wateren 1995; Etzelmüller et al. 1996; Boulton et al. 1999; Evans and Rea 1999; Benediktsson et al. 2008). These landforms are sometimes referred to as push moraines or push moraine complexes in this context in the literature (e.g. Hart and Watts, 1997; Boulton et al. 1999; van der Meer 2004; Christoffersen et al. 2005), although these terms are problematic as they are also used for a broad range of landforms at various scales and with often quite different morphologies and inferred genetic origins (cf. Bennett, 2001). To avoid possible confusion, we use the term composite ridge system as defined by Aber et al. (1989) throughout this contribution.

Composite ridge systems at modern glacier margins are often coincident with known surge-type glaciers (e.g. Croot 1988a; Huddart and Hambrey 1995; Boulton et al. 1996; 1999; Hart and Watts 1997; Evans and Rea 1999; Benediktsson et al. 2008, 2009, 2015; Kristensen et al. 2009a, b; Roberts et al. 2009). Most of the above studies imply at the very least a direct link between composite ridge systems (including thrust-block moraines) and glacier surging, although alternative, non-surging genetic origins have been suggested in the past for similar 
landforms. These alternatives include sustained glacier advance into proglacial permafrost (e.g. Kälin, 1971) and englacial thrusting within polythermal glacier snouts (e.g. Hambrey and Huddart, 1995; Huddart and Hambrey, 1996). The awareness of a link between composite ridge systems and surge-type glaciers stems in part from the pioneering work of Croot (1988a), who identified 29 composite ridge systems in Svalbard, 27 of which were located at the margins of known or inferred (based on the presence of looped moraines; cf. Meier and Post 1969) surgetype glaciers (Fig. 1). Similar correlations have also been recognised in Iceland (e.g. Croot 1988b; Benediktsson et al. 2008, 2009, 2010, 2015; Ingólfsson et al. 2016), West Greenland (e.g. Yde et al. 2005; Roberts et al. 2009; Larsen et al. 2010), the Canadian Arctic (e.g. Copland et al. 2003) and High-Arctic Russia (Grant et al. 2009). As a result, glacitectonic composite ridge systems are recognised as being part of a diagnostic suite of geomorphological indicators, or landsystem, of glacier surging in modern environments (Evans and Rea 1999, 2003). A second key feature of the surging glacier landsystem is crevasse-squeeze ridges (CSRs; Sharp 1985; Evans and Rea 1999, 2003), which have been genetically linked to processes active during surge cycles. CSRs are formed through the injection of deformable sediments into basal crevasses that open in response to enhanced ice velocities in the surge active phase. These subsequently melt out as foreland geometrical ridge networks upon surge termination and glacier stagnation. It is widely accepted that, although individual CSRs are not necessarily diagnostic of surging per se, their arrangement in dense networks at glacier margins is. These networks are characterised by multiple ridges oriented oblique and transverse (and occasionally normal) to ice flow (Sharp 1985; Evans and Rea 1999, 2003; Kjær et al. 2008; Rea and Evans 2011; Schomacker et al. 2014; Lovell et al. 2015a; Evans et al. 2016; Farnsworth et al. 2016). Better understanding of the geomorphology produced by surging, including composite ridge systems and CSR networks, is important in order to help identify previously unrecognised surge-type glaciers in modern environments (e.g. Ottesen and Dowdeswell 2006; Grant et al. 2009; Streuff et al. 2015; Farnsworth et al. 2016). This in turn can improve interpretations of possible surging behaviour of ice lobes at the margins of former ice sheets (e.g. Clayton et al. 1985; Evans and Rea 1999; Evans et al. 1999, 2008; Benn and Clapperton 2000; Kehew et al. 2005; Davies et al. 2009; Evans and Thomson 2010; Boston et al. 2010; Lovell et al. 2012; Darvill et al. 2016; Gribenski et al. 2016).

In this contribution, we aim to investigate the coincidence between composite ridge systems and surge-type glaciers in Svalbard. To achieve this, we revisit and update Croot's (1988a) study of composite ridge systems in Spitsbergen with the benefit of $~ 30$ years of research on surge-type glaciers and surge geomorphology alongside access to high-resolution 
aerial photographs of the entire archipelago via the Norwegian Polar Institute (NPI)'s online archive TopoSvalbard (toposvalbard.npolar.no). We produce an updated distribution map of composite ridge systems and examine their correlation with both documented surge-type glaciers and glaciers that have not been observed to surge, but contain geomorphological evidence that is indicative of surging in the form of CSR networks (based on Farnsworth et al. (2016)). We use this combined dataset to refine the minimum estimate of the number of glaciers in Svalbard that are likely to be of surge-type. This study contributes a database that we hope will be of use to future research focused on surge geomorphology and surge-type glacier distribution.

\section{Svalbard and glacier surges}

Approximately $57 \%\left(\sim 34,000 \mathrm{~km}^{2}\right)$ of the total surface area of Svalbard is glacierized (Nuth et al. 2013), comprising >2,000 glaciers ranging from large $\left(\sim 1000 \mathrm{~km}^{2}\right)$ ice cap outlet glaciers to small $\left(<1 \mathrm{~km}^{2}\right)$ cirque glaciers (cf. Hagen et al. 1993; Fig. 1). The latter account for $\sim 56 \%$ of all glaciers, but cover only $\sim 1 \%$ of the total glacierized area (Hagen et al. 1993). By comparison, $\sim 7 \%$ of all glaciers are tidewater- or marine-terminating, but these drain $\sim 68 \%$ of the total glacierized area (Błaszczyk et al. 2009; Nuth et al. 2013). Glacier surges are commonly observed in Svalbard. They are characterised by long quiescent phases of ice stagnation and frontal recession lasting $\sim 40-150$ years, punctuated by short ( $\sim 3-10$ years) active or surge phases. During the surge phase, ice velocities increase between 10 to 1000 times and the glacier front typically advances several kilometres (Dowdeswell et al. 1991; Hagen et al. 1993; Murray et al. 2003). Previous inventories have documented a total of 280 glaciers (12.8\% of all glaciers) as being of surge-type (Croot 1988a; Dowdeswell et al. 1991; Lefauconnier and Hagen 1991; Hamilton 1992; Hagen et al. 1993; Liestøl 1993; Dowdeswell et al. 1999; Jiskoot et al. 2000; Dowdeswell and Benham 2003; Błaszczyk et al. 2009; Sund et al. 2009).

Due to the multi-decadal return periods of glacier surges and the remote nature of the archipelago, many surges are likely to have gone undetected (Dowdeswell et al. 1991; Farnsworth et al. 2016; Lønne 2016), and thus the figure quoted above represents a minimum value for the surge-type glacier total. It is also recognised that some glaciers may have surged in the past (e.g. during the Little Ice Age maximum 1900 AD) but are no longer in the surge cycle (e.g. Hodgkins et al. 1999; Hansen 2003; Małecki et al. 2013; Lovell et al. 2015b; Farnsworth et al. 2016). This is largely in response to the strongly negative mass balance experienced by all Svalbard glaciers during the $20^{\text {th }}$ and $21^{\text {st }}$ centuries (James et al. 2012; Nuth 
et al. 2013; Małecki 2016). Several previous studies have attempted to refine the proportion of surge-type glaciers through a variety of approaches, including:

(i) Estimates based on a combination of both observed surges and glaciological and geomorphological evidence for surging (Lefauconnier and Hagen 1991; Hagen et al. 1993).

(ii) Probabilistic (Hamilton and Dowdeswell 1996) and multivariate (Jiskoot et al. 1998) statistical methods that use various parameters including glacier geometry (e.g. length, aspect, slope, presence/number of tributaries), underlying geology, mass-balance measurements and thermal regime of a sub-sample of glaciers.

(iii) The identification of diagnostic geomorphological evidence for surging in the form of CSR networks on glacier forelands (Farnsworth et al. 2016).

These studies provide a wide range of estimates for the likely proportion of surge-type glaciers in Svalbard, from 13\% (Jiskoot et al. 1998), >32\% (Farnsworth et al. 2016), and 36\% (Hamilton and Dowdeswell 1996) to 90\% (Lefauconnier and Hagen 1991; Hagen et al. 1993).

\section{Composite ridge system geomorphology}

Composite ridge systems vary in size, morphology, internal structure and sediment composition, and location relative to the glacier that was responsible for forming them. There are, however, a number of shared geomorphological characteristics that are linked to the inferred process of formation at the margins of surging glaciers, and these are listed in Table 1. Typically, composite ridge systems can be described as multi-ridged sediment masses located in a proglacial frontal or latero-frontal position (Fig. 2), although they can also be found at lateral glacier margins. Most are no longer in contact with the glacier and are clearly distinguishable from de-icing forelands, which are characterised by hummocky terrain, abundant meltwater pools and outwash deposits. This distinction reflects the difference between composite ridge systems, formed in a proglacial position, and de-icing forelands comprising sub-/supraglacial deposits left-behind by glacier recession during the quiescent phase of the surge cycle (e.g. Lønne 2016). The few studies that have investigated the internal structure of glacitectonic composite ridge systems in Svalbard report stacked and contorted sequences consisting of predominantly sorted and fine-grained sediment, typically with varying compositions of mud, sand and gravel (e.g. Garwood and Gregory 1898; Lamplugh 1911; Gripp 1929; Hambrey and Huddart 1995; Boulton et al. 1996, 1999; Hart and Watts 1997; Kristensen et al. 2009a, b). This variation is found both between different complexes and across a single complex (e.g. Boulton et al. 1996, 1999). 


\section{Identifying composite ridge systems from aerial photographs}

A systematic assessment of glacier forelands was undertaken using TopoSvalbard aerial photographs in order to identify the location of composite ridge systems using the criteria listed in Table 1. A combination of oblique (captured in 1936) and vertical (captured in 2008-2012) aerial photographs were assessed. In order to reduce the chance of missing any composite ridge systems, the Croot (1988a) composite ridge system and Hagen et al. (1993) push moraine inventories were examined in detail, alongside all glaciers documented as surge-type (Croot, 1988a; Farnsworth et al. 2016; and reference therein) and those likely to have surged based on the presence of CSR networks (Farnsworth et al. 2016).

Composite ridge systems have only been included if they meet most, if not all, of the criteria outlined in Table 1. Complexes were identified from aerial photographs based on:

- Geomorphological characteristics, e.g. a large, often arcuate in planform sediment accumulation with a series of multiple adjacent ridges on the surface aligned perpendicular to glacier flow.

- Location, e.g. in a proglacial frontal/latero-frontal position.

- Their smooth surface texture due to the fine-grained sediment they typically comprise. This allows them to be differentiated from surrounding terrain consisting of a wider range of grain sizes, up to and including large boulders, as commonly found on deicing forelands (Fig. 2).

- The presence of large meltwater channels incised into the ridges (e.g. Figs 2a, 2b and 2e-h). These typically form deep gorges within the complex that highlight the thickness of the sediment accumulation, especially when compared to meltwater channels in adjacent areas of outwash.

To be more confident of the glacitectonic origin of composite ridge systems, it is desirable to also have information on their internal structure. This is not possible to determine conclusively in this study due to its remote sensing approach. However, based on the shared diagnostic geomorphological characteristics of composite ridge systems (Table 1) displayed both by those identified only from aerial photographs and those also previously subjected to detailed internal investigations (e.g. Garwood and Gregory 1898; Gripp 1929; Hambrey and Huddart 1995; Boulton et al. 1996, 1999; Hart and Watts 1997; Kristensen et al. 2009a, b), we suggest these have a common glacitectonic origin. 
A number of push moraines or push moraine complexes reported in the literature have not been included as the geomorphological evidence is not sufficiently compelling, and typically justifications for their classification in the first instance are absent or unclear. This may in part be due to the range of landforms that have come under the broad category of push moraines in the glacial geomorphological literature (cf. Bennett 2001). An example of this is Hagen et al. (1993), which lists 283 glaciers as having push moraines but do not define what criteria this is based on. It is clear that some of these (e.g. Arnesenbreen, Deltabreen, Gandbreen and Seidbreen, to name a few) are composite ridge systems as defined by the criteria in Table 1, but a large number are not. Similarly, several glaciers (e.g. Hessbreen, Renardbreen and Scottbreen) identified by Croot (1988a) also do not meet our geomorphological criteria for composite ridge systems (Table 1). It is possible some of these landforms formed during surges, but their geomorphology as assessed from aerial photographs is not diagnostic of glacitectonic composite ridge systems, and therefore additional information (e.g. direct observations of formation, investigations of internal structure) would be necessary before such a classification could be made.

A further explanation for the misidentification of some composite ridge systems in previous studies is that they share some geomorphological characteristics with landformsediment assemblages that are genetically very different (i.e. not of a glacitectonic origin). Specifically, both controlled moraines (cf. Evans 2009; Figs 3a and 3b) and fluvially-dissected ice-marginal sediment masses (Figs 3c and 3d) appear to consist of multiple linear ridges, which in some contexts is not dissimilar to composite ridge systems.

Controlled moraines (e.g. Figs $3 \mathrm{a}$ and $3 \mathrm{~b}$ ) are supraglacially-deposited ice-cored landform assemblages that have inherited linear surface features from debris-rich structures within the parent ice (cf. Evans 2009). These features are common in the forelands of polythermal glaciers. Debris derived from various sources (e.g. subglacial, rockfall, englacial meltwater channels, proglacial) and incorporated into the ice by several process such as basal freeze-on (e.g. Alley et al. 1997), shear-plane development (e.g. Sletten et al. 2001; Lovell et al. 2015b), apron entrainment (e.g. Evans 1989) and via crevasse/fracture networks (e.g. Rea and Evans 2011), melts out on the surface at the glacier front to form supraglacial debris cover. During glacier recession and frontal thinning, ice beneath thicker debris cover (e.g. at the emergence of a debris-rich structure) is preserved relative to surrounding areas, creating a topographic inversion controlled by the delivery of debris to the surface within structures. This creates ice-cored moraine sequences that display clear linearity reflecting the englacial structures from which the debris is derived, typically preserving the shape of the former glacier 
front (e.g. Fig. 3b). In many cases, the surface linearity of controlled moraine can be traced into a lateral (e.g. flow-parallel structure) position (Figs $3 \mathrm{a}$ and 3b). Controlled moraine assemblages also typically display evidence for degradation and reworking due to de-icing thermo-erosion processes (e.g. Etzelmüller et al. 1996; Schomacker and Kjær 2008), such as debris flows (e.g. Fig. 3b). By contrast, composite ridge systems are formed proglacially and, although they can incorporate pre-existing buried glacier ice and/or glacier naled located on forelands (e.g. Yde et al. 2005; Roberts et al. 2009), the ice content of the resultant composite ridges would be significantly lower than areas of controlled moraine derived from englacial debris-rich structures. As a result, de-icing indicators are usually absent or minimal in composite ridge systems (e.g. Fig. 2 and Table 1).

Fluvially-dissected moraines or ice-marginal sediment masses (e.g. Figs $3 \mathrm{c}$ and $3 \mathrm{~d}$ ) also display linearity and contain meltwater canyons/gorges that are not dissimilar to those seen within composite ridge systems (e.g. Figs $2 \mathrm{a}$ and $2 \mathrm{~g}$ ). These areas are typically found towards the lateral margins of glaciers, or occasionally in latero-frontal positions (e.g. Figs $3 \mathrm{c}$ and 3d). They are formed where lateral meltwater channels have eroded into an ice-marginal sediment mass, creating an inset sequence of channels that are similarly aligned and therefore give the impression of multiple ridges within a depositional landform (Figs 3c and 3d). However, the channels within fluvially-dissected sediment masses often meander, giving the same form to the ridges as the adjacent channels (e.g. Fig. 3c). In composite ridge systems, although the deep gorges cutting through the systems may meander (e.g. Figs $2 a, 2 b$ and $2 \mathrm{e}-\mathrm{h}$ ), the ridges themselves are straight to curvilinear rather than having a sinuous form (Table 1).

\section{Distribution of composite ridge systems and surge-type glaciers in Svalbard}

Using the geomorphological criteria outlined in Table 1, 50 composite ridge systems are identified across the Svalbard archipelago (Fig. 1 and Table 2). 19 of these are located at the terrestrial margins of marine-terminating or tidewater glaciers (e.g. Figs 4a and 4c-f) and 31 are at the margins of land-terminating glaciers (e.g. Figs $2 \mathrm{a}-\mathrm{h}$ and $5 \mathrm{~b}$ ). Of the latter glaciers, nine currently terminate in proglacial lakes (e.g. Figs 2c, 2e and 2g). Of the 50 composite ridge systems, 17 were listed by Croot (1988a; out of a total of 29 identified) and 34 were listed as push moraines by Hagen et al. (1993; out of a total of 283 identified). Our inventory also includes composite ridge systems that have previously been described at Duckwitzbreen and Ulvebreen (Gripp 1929), and Paulabreen (Kristensen et al. 2009a, b), but that did not feature in either the Croot (1988a) or Hagen et al. (1993) studies. We have therefore identified 12 
composite ridge systems that, to the best of our knowledge, have not previously been reported. These are: Augnebreen, Austre Kvitisen, BEØ-13 (as named in Farnsworth et al. 2016; located on Edgeøya at $77.8307^{\circ} \mathrm{N}, 22.5578^{\circ} \mathrm{E}$ ), Besselsbreen, Gardebreen, Koristkabreen, Kosterbreen, Kvastbreen, Laubefjellebreen, Mittag-Lefflerbreen, Schweigaardbreen and Winsnesbreen (Fig. 4).

Almost all of the 50 composite ridge systems we have identified are coincident with known or inferred surge-type glaciers. 30 are located at the margins of documented surge-type glaciers (according to Croot (1988a) and Farnsworth et al. (2016, and references therein)) and a further 19 are located on forelands that also contain CSR networks (cf. Farnsworth et al. 2016). Therefore, Schweigaardbreen in Nordaustlandet (Fig. 4f) is the only glacier with a composite ridge system that has not previously been reported or inferred (based on the presence of CSRs) to be of surge-type. In order to assess the identified spatial distribution of composite ridge systems, the Svalbard archipelago is divided into six regions following the approach of Farnsworth et al. (2016): Northwest (NWS), Northeast (NES), Central (CS) and Southern (SS) Spitsbergen; Barentsøya and Edgeøya (BEØ); and Nordaustlandet (NA). The largest number of composite ridge systems (34) are located in Spitsbergen, with 12 in NWS, nine in SS, eight in NES, and five in CS (Fig. 1 and Table 3). Of the other main islands in the archipelago, there are ten composite ridge systems in Edgeøya, four in Barentsøya and two in Nordaustlandet (Fig. 1 and Table 3).

Figure 5 shows the distribution of composite ridge systems, documented surge-type glaciers and CSR networks compared to the total number of glaciers and number of glaciers $>1 \mathrm{~km}^{2}$ (according to Hagen et al. 1993). The reason for including the number of glaciers $>1 \mathrm{~km}^{2}$, which constitute $46.7 \%$ of all glaciers in Svalbard (Table 3), is based on the observations that: (i) none of the identified composite ridge systems in this study are coincide nt with glaciers smaller than this size; and (ii) with very few exceptions (e.g. Sund et al. 2009), almost all documented surge-type glaciers in Svalbard are significantly larger than this (cf. Sevestre and Benn 2015). These data show that glaciers with composite ridge systems constitute $2.3 \%$ of all glaciers in Svalbard (and $4.9 \%$ of all glaciers $>1 \mathrm{~km}^{2}$ ). This proportion varies regionally, with the highest in BEØ (4.1\% of all glaciers in the region) and the lowest in NA $(0.9 \%)$ (Fig. 5 and Table 3).

As a point of wider interest, the distribution of documented surge-type glaciers by region reveals that $\mathrm{SS}$ has the largest proportion at $35.1 \%$ of all glaciers in the region, and BEØ the lowest at $4.1 \%$ (Fig. 5 and Table 3). If we include those glaciers that have not been documented as surge-type but contain indicative geomorphological evidence for surging in the 
form of CSR networks and composite ridge systems, this increases for all regions (Table 3). For Svalbard as a whole, this indicates that at least $32.6 \%$ of all glaciers are of surge-type, which is a significant increase on the figure of $12.8 \%$ based solely on documented surge-type glaciers (cf. Farnsworth et al. 2016).

\section{Discussion}

What does the distribution of composite ridge systems tell us about their formation?

All but one of the identified composite ridge systems in Svalbard are at the margins of glaciers that have either been previously documented as surge-type (30 glaciers) or contain compelling geomorphological evidence for surging in the form of CSR networks (19 glaciers; Table 2). This provides clear support for the suggestion that composite ridge systems in Svalbard are formed by glacier surges (cf. Croot 1988a).

Our investigation reveals that composite ridge systems are distributed across the four largest islands in the archipelago (Fig. 1), but overall are very restricted in number (50, i.e. only $2.3 \%$ of all glaciers). This is particularly apparent when compared to the number of documented surge-type glaciers (280, or $12.8 \%$ of all glaciers) and glaciers with CSR networks (612, or $28 \%$ of all glaciers; Table 3). Furthermore, out of the 711 glaciers that are thought to be of surge-type (32.6\% of the total number of glaciers), this means that only $7 \%$ have formed (or preserved) composite ridge systems, considerably fewer than those that have CSR networks at their margins $(86 \%)$, for example. This implies that composite ridge system formation at the margin of a rapidly advancing glacier is dependent on specific conditions, as they clearly do not form (or are not preserved) at all surge-type glaciers. Although a full assessment of these conditions is beyond the scope of this study, previous investigations on composite ridge formation in Svalbard provide some indication of what these are likely to be.

Firstly, the availability of a thick sequence of fine-grained, deformable sediments on the pre-surge foreland is likely to be necessary for composite ridge formation. This is based on investigations of their internal structure, which demonstrate that most are predominantly composed of sorted and fine-grained sediment ranging from muds to gravel. This reflects a range of depositional environments including shallow marine (e.g. Lamplugh, 1911; Boulton et al. 1996; Hart and Watts 1997; Kristensen et al. 2009a, b); glacilacustrine (e.g. Boulton et al. 1999), and glacifluvial outwash (e.g. Garwood and Gregory, 1898; Hambrey and Huddart 1995; Hart and Watts 1997; Boulton et al. 1999). High pore water pressures within these sediments, perhaps driven by enhanced meltwater drainage from the glacier during the surge, 
332 is likely to be required in order to minimise resistance in the deforming foreland (Boulton et

333

334

335

336

337

338

339

340

341

342

343

344 al. 1999).

Secondly, the role of permafrost and partially-frozen conditions within foreland sediments has been suggested to be important for composite ridge system formation, as this facilitates the transmission of stress through the foreland as the glacier advances (e.g. Etzelmüller et al. 1996; Boulton et al. 1999). Boulton et al. (1999) also suggest that the presence of permafrost serves to extend the zone of high pore water pressures further into the proglacial sediments than if the ground was unfrozen.

Thirdly, it is probably necessary for the glacier margin to be initially stationary in order to allow the development of an ice-contact zone with a sufficiently thick proglacial sediment accumulation. This is then followed by a frontal advance of sustained duration over a distance ranging from 100 s to 1000 s of metres, during which the well-defined ice-contact zone promotes the transmission of stresses into the sediments (e.g. Boulton et al. 1999).

Finally, in order to preserve composite ridge systems, low compositions of buried glacier ice within the initial foreland sediments and thus within the resultant complex are required. This means that degradation and/or (fluvial) erosion of the composite ridge system over time is much lower compared to supraglacial moraine deposits, as indicated by the typical absence of de-icing evidence.

\section{How can the discrepancies with previous inventories be explained?}

Our inventory presents some discrepancies when compared to previous studies, both in terms of the number of composite ridge systems identified and individual classifications. Misidentification of composite ridge systems could result in incorrect conclusions being drawn on both the genetic origin of the moraine system and, based on the correlation between composite ridge systems and surge-type glaciers highlighted in this and other studies, potentially whether a glacier has surged or not. In most cases where we disagree with composite ridge systems or push moraines identified in Croot (1988a) and Hagen et al. (1993), we suggest it is due to the following reasons:

(i) The use of the broad term 'push moraine' in Hagen et al. (1993), which can describe a range of landforms at various scales and with quite different morphologies and inferred genetic origins (cf. Bennett, 2001).

(ii) The misidentification of moraine areas that contain or appear to contain multiple linear ridges, but are actually derived from englacial structural control (cf. Evans 2009) and/or ice-marginal fluvial dissection rather than glacitectonic deformation of foreland sediments. 
(iii) Moraine systems may have formed proglacially during surges, but do not display the characteristic form that allows them to be identified as composite ridge systems based on geomorphology alone. These might include small single- or double-ridged push moraines that geomorphologically cannot be differentiated from supraglacially-derived ice-cored moraines, and would therefore require additional information (e.g. investigations of internal structure) in order to be classified. Examples of this may include the composite ridge system reported at Hessbreen (Croot 1988a), the push moraine complex at Elisebreen (Christoffersen et al. 2005), and thrust-block moraines at the margins of Kongsvegen (Bennett et al. 1999), none of which meet the geomorphological criteria for composite ridge systems outlined in Table 1.

(iv) Examples where the complex appears to have been formed by a combined glacier tongue that has since split into two separate glaciers during recession. In these examples, the composite ridge systems have been attributed to the glacier that appears to have been the moredominant flow unit based on supraglacial moraine patterns (e.g. Universitetsmorenen is attributed to Lisbetbreen rather than Universitetsbreen, as previously suggested by Croot (1988a)).

\section{How many glaciers are of surge-type in Svalbard?}

Based on our study and Farnsworth et al. (2016), who identified CSR networks using TopoSvalbard, we suggest that at least 711 glaciers, or $32.6 \%$ of the total population, are of surge-type. This number comprises 280 that have previously been documented as surging glaciers and an additional 431 glaciers that display geomorphology that is indicative of surging. This is a minimum value because:

(i) Not all documented surge-type glaciers have CSR networks (cf. Farnsworth et al. 2016) and/or composite ridge systems at their margins, and thus it is clear that glaciers can surge without producing (or preserving) such landforms. This is likely to particularly be the case for a number of small valley glaciers $\left(\sim 3 \mathrm{~km}^{2}\right.$; e.g. Scott Turnerbreen; Hodgkins et al. 1999), where evidence for past surges or surge-like behaviour may only be preserved englacially and does not appear to survive de-icing (e.g. Lovell et al. 2015b).

(ii) Tidewater glaciers that have undergone unobserved surges may only record geomorphological evidence for this on the seafloor (e.g. Streuff et al. 2015; Flink et al. 2017), and therefore if their forelands have not been the subject of a submarine investigation then evidence indicating surge behaviour may not yet have been found.

These observations suggest that at least one-third of all glaciers in Svalbard surge or have surged, but it is worth noting that over half of the total population of glaciers $(\sim 53 \%)$ is 
400

401

402

403

404

405

406

407

408

409

410

411

412

413

414

415

416

417

418

419

420

421

422

423

424

425

426

427

428

\section{Conclusion}

430 Glacitectonic composite ridge systems are found at the margins of 50 glaciers across the 431

smaller than $\sim 1 \mathrm{~km}^{2}$ (Hagen et al. 1993; Fig. 5). Although glaciers of this size have been reported to surge (e.g. Sund et al. 2009), the vast majority of documented surge-type glaciers, glaciers with CSR networks, and glaciers with composite ridge systems, are larger than this (cf. Sevestre and Benn 2015; Farnsworth et al. 2016). Therefore, if the suggested minimum number of surge-type glaciers (711) is reported as a proportion of only those glaciers larger than $1 \mathrm{~km}^{2}$, this value increases to $69.8 \%$.

\section{How useful is the identification of composite ridge systems from remote sensing data?}

Identifying composite ridge systems from imagery is possible because they have a characteristic form dependent on the inferred processes of glacitectonic formation at the margin of a rapidly advancing glacier. However, as with any such investigation based solely on remote sensing imagery, it is possible that some composite ridge systems have been misidentified or missed. It is also not possible to investigate the internal structure of composite ridge systems through remote sensing analysis, which would provide further support for their inferred glacitectonic origin. We have tried to reduce these potential issues as much as possible through rigorous application of mapping criteria (Table 1). Based on our investigation, we suggest that the majority of composite ridge systems can be easily identified from aerial photographs, as is also the case for CSR networks (e.g. Farnsworth et al. 2016). Their coincidence with surgetype glaciers indicates that, like CSR networks, composite ridge systems in Svalbard can be linked to glacier surging with some confidence. CSRs are clearly formed more often than composite ridge systems during surges, but their smaller scale $(\sim 1-2 \mathrm{~m}$ wide, $100 \mathrm{~s}$ of metres long) means they often can only really be identified from high-resolution imagery (e.g. at least $\sim 1 \mathrm{~m}$ pixel resolution). Composite ridge systems, on the other hand, are large enough $(\sim 300 \mathrm{~m}$ wide, $\sim 1000 \mathrm{~m}$ long) that they could potentially also be identified from medium to high resolution satellite imagery in other surge clusters where aerial photograph coverage is less complete, such as in the Canadian Arctic (e.g. Evans and England 1991; Copland et al. 2003), West Greenland (e.g. Yde et al. 2005; Roberts et al. 2009) and High-Arctic Russia (Grant et al. 2009).

Svalbard archipelago. Of these glaciers, 19 are documented to be of surge-type and a further 30 display indicative geomorphological evidence for surging in the form of crevasse-squeeze 
ridge (CSR) networks. This provides support for observations first made by Croot (1988a) that composite ridge systems are uniquely linked to surging in Svalbard. However, out of the 711 glaciers that are thought to be of surge-type (32.6\% of all glaciers in Svalbard), only $7 \%$ have produced composite ridge systems, which is considerably fewer than those with CSR networks at their margins. This confirms that specific conditions are necessary for the formation and preservation of composite ridge systems, which may include the availability on the pre-surge foreland of a thick sequence of deformable sediments, high pore water pressures within the foreland sediments, and the presence of permafrost.

These observations contribute to our understanding of the links between composite ridge systems and surge-type glaciers, which requires further investigation at other known surge clusters (e.g. the Canadian Arctic, West Greenland and High-Arctic Russia). This work also has the potential to provide additional support for the interpretations of glacitectonic sequences at the margins of former Quaternary ice masses.

\section{References}

Aber JS, Croot DG, Fenton, MM (1989) Glaciotectonic Landforms and Structures. Kluwer, Dordrecht.

Alley RB, Cuffey KM, Evenson EB, Strasser JC, Lawson DE, Larson GJ (1997) How glaciers entrain and transport basal sediment: Physical constraints. Quaternary Science Reviews 16(9): 1017-1038

Bakker MA, van der Meer JJM (2003) Structure of a Pleistocene push moraine revealed by GPR: the eastern Veluwe Ridge, The Netherlands. Geological Society, London, Special Publications 211(1): 143-151

Benediktsson ÍÖ, Möller P, Ingólfsson Ó, van der Meer JJM, Kjær KH, Krüger J (2008) Instantaneous end moraine and sediment wedge formation during the 1890 glacier surge of Brúarjökull, Iceland. Quaternary Science Reviews 27(3): 209-234

Benediktsson ÍÖ, Ingólfsson Ó, Schomacker A, Kjær KH (2009) Formation of submarginal and proglacial end moraines: implications of ice-flow mechanism during the 1963-64 surge of Brúarjökull, Iceland. Boreas 38:440-457

Benediktsson ÍÖ, Schomacker A, Lokrantz H, Ingólfsson Ó (2010) The 1890 surge end moraine at Eyjabakkajökull, Iceland: a re-assessment of a classic glaciotectonic locality. Quaternary Science Reviews 29:484-506 
Benediktsson ÍÖ, Schomacker A, Johnson MD, Geiger AJ, Ingólfsson Ó, Guðmundsdóttir ER (2015) Architecture and structural evolution of an early Little Ice Age terminal moraine at the surge-type glacier Múlajökull, Iceland. Journal of Geophysical Research: Earth Surface 120(9):1895-1910

Benn DI, Clapperton CM (2000) Pleistocene glacitectonic landforms and sediments around central Magellan Strait, southernmost Chile: evidence for fast outlet glaciers with coldbased margins. Quaternary Science Reviews 19(6):591-612

Bennett MR (2001) The morphology, structural evolution and significance of push moraines. Earth-Science Reviews 53:197-236

Bennett MR, Hambrey MJ, Huddart D, Glasser NF, Crawford K (1999) The landform and sediment assemblage produced by a tidewater glacier surge in Kongsfjorden, Svalbard. Quaternary Science Reviews 18(10):1213-1246

Błaszczyk M, Jania JA, Hagen JO (2009) Tidewater glaciers of Svalbard: Recent changes and estimates of calving fluxes. Polish Polar Research 30(2):85-142

Boston CM, Evans DJA, Ó Cofaigh C (2010) Styles of till deposition at the margin of the Last Glacial Maximum North Sea lobe of the British-Irish Ice Sheet: an assessment based on geochemical properties of glacigenic deposits in eastern England. Quaternary Science Reviews 29(23):3184-3211

Boulton GS, Van der Meer JJM, Hart JK, Beets DJ, Ruegg GHJ, van der Wateren FM, Jarvis $\mathrm{J}$ (1996) Till and moraine emplacement in a deforming bed surge-an example from a marine environment. Quaternary Science Reviews 15(10):961-987

Boulton GS, van der Meer JJM, Beets DJ, Hart JK, Ruegg GHJ (1999) The sedimentary and structural evolution of a recent push moraine complex: Holmstrømbreen, Spitsbergen. Quaternary Science Reviews 18:339-371

Christoffersen P, Piotrowski JA, Larsen NK (2005) Basal processes beneath an Arctic glacier and their geomorphic imprint after a surge, Elisebreen, Svalbard. Quaternary Research 64(2):125-137

Clayton L, Teller J, Attig J (1985) Surging of the southwestern part of the Laurentide Ice Sheet, Boreas 14(3):235-241

Copland L, Sharp MJ, Dowdeswell JA (2003) The distribution and flow characteristics of surge-type glaciers in the Canadian High Arctic. Annals of Glaciology 36(1):73-81

Croot DG (1988a) Glaciotectonics and surging glaciers: a correlation based on Vestspitsbergen, Svalbard, Norway. In: Glaciotectonics: forms and processes. Croot DG (ed) Balkema, Amsterdam, pp 49-62 
Croot DG (1988b) Morphological, structural and mechanical analys is of neoglacial ice-pushed ridges in Iceland. In: Glaciotectonics: forms and processes. Croot DG (ed) Balkema, Amsterdam, pp 33-47

Darvill CM, Stokes CR, Bentley MJ, Evans DJA, Lovell H (2016) Dynamics of former ice lobes of the southernmost Patagonian Ice Sheet based on a glacial landsystems approach. Journal of Quaternary Science. DOI: 10.1002/jqs.2890

Davies BJ, Roberts DH, O’ Cofaigh C, Bridgland DR, Riding JB, Phillips ER, Teasdale DA (2009) Interlobate ice-sheet dynamics during the Last Glacial Maximum at Whitburn Bay, County Durham, England. Boreas 38:555-578

Dowdeswell JA, Benham TJ (2003) A surge of Perseibreen, Svalbard, examined using aerial photography and ASTER high resolution satellite imagery. Polar research 22(2):373-383

Dowdeswell JA, Hamilton GS, Hagen JO (1991) The duration of the active phase on surgetype glaciers: contrasts between Svalbard and other regions. Journal of Glaciology 37(127):388-400

Dowdeswell JA, Unwin B, Nuttall AM, Wingham DJ (1999) Velocity structure, flow instability and mass flux on a large Arctic ice cap from satellite radar interferometry. Earth and Planetary Science Letters 167(3):131-140

Etzelmüller B, Hagen J, Vatne G, Ødegård R, Sollid J (1996) Glacial debris accumulation and sediment deformation influenced by permafrost: examples from Svalbard. Annals of Glaciology 22:53-62

Evans DJA (1989) Apron entrainment at the margins of sub-polar glaciers, north-west Ellesmere Island, Canadian High Arctic. Journal of Glaciology 35(121):317-324

Evans DJA (2009) Controlled moraines: origins, characteristics and palaeoglaciological implications. Quaternary Science Reviews 28(3):183-208

Evans DJA, England J (1991) High Arctic thrust block moraines. The Canadian Geographer/Le Géographe canadien 35(1):93-97

Evans DJA, Rea BR (1999) Geomorphology and sedimentology of surging glaciers: a landsystems approach. Annals of Glaciology 28:75-82

Evans DJA, Rea BR (2003) Surging glacier landsystem. In: Glacial Landsystems. Evans DJA (ed) Arnold, London, pp 259-288

Evans DJA, Thomson SA (2010) Glacial sediments and landforms of Holderness, eastern England: A glacial depositional model for the North Sea Lobe of the British-Irish Ice Sheet. Earth-Science Reviews 101:147-189 
Evans DJA, Lemmen DS, Rea BR (1999) Glacial landsystems of the southwest Laurentide Ice Sheet: modern Icelandic analogues. Journal of Quaternary Science 14(7):673-691

Evans DJA, Clark CD, Rea BR (2008) Landform and sediment imprints of fast glacier flow in the southwest Laurentide Ice Sheet. Journal of Quaternary Science 23(3):249-272

Evans DJA, Storrar RD, Rea BR (2016) Crevasse-squeeze ridge corridors: Diagnostic features of late-stage palaeo-ice stream activity. Geomorphology 258:40-50

Farnsworth WR, Ingólfsson Ó, Retelle M, Schomacker A (2016) Over 400 previously undocumented Svalbard surge-type glaciers identified. Geomorphology 264:52-60

Flink AE, Noormets R, Fransner O, Hogan KA, O’Regan M, Jakobsson M (2017) Past ice flow in Wahlenbergfjorden and its implications for late Quaternary ice sheet dynamics in northeastern Svalbard. Quaternary Science Reviews 163:162-179

Garwood EJ, Gregory JW (1898) Contributions to the glacial geology of Spitsbergen. Quarterly Journal of the Geological Society 54:197-227

Grant KL, Stokes CR, Evans IS (2009) Identification and characteristics of surge-type glaciers on Novaya Zemlya, Russian Arctic. Journal of Glaciology 55(194):960-972

Gribenski N, Jansson KN, Lukas S, Stroeven AP, Harbor JM, Blomdin R, Ivanov MN, Heyman J, Petrakov DA, Rudoy A, Clifton T, Lifton NA, Caffee MW (2016) Complex patterns of glacier advances during the late glacial in the Chagan Uzun Valley, Russian Altai. Quaternary Science Reviews 149:288-305

Gripp K (1929) Glaciologische und geologische Ergebnisse der Hamburgischen SpitzbergenExpedition 1927. Abhandlungen der naturwissenschaftlichen Verein Hamburg, Hamburg

Hagen JO (1988) Glacier surge in Svalbard with examples from Usherbreen. Norsk Geografisk Tidsskrift 42:204-213

Hagen JO, Liestøl O, Roland E, Jørgensen T (1993) Glacier atlas of Svalbard and Jan Mayen. Norwegian Polar Institute Meddelelser 129:1-141

Hambrey MJ, Huddart D (1995) Englacial and proglacial glaciotectonic processes at the snout of a thermally complex glacier in Svalbard. Journal of Quaternary Science 10(4):313326

Hamilton GS (1992) Investigations of surge-type glaciers in Svalbard. PhD Thesis, University of Cambridge.

Hamilton GS, Dowdeswell JA (1996) Controls on glacier surging in Svalbard. Journal of Glaciology 42(140):157-168 
Hansen S (2003) From surge-type to non-surge-type glacier behaviour: midre Lovénbreen, Svalbard. Annals of Glaciology 36(1):97-102

Hart JK (1990) Proglacial glaciotectonic deformation and the origin of the Cromer Ridge push moraine complex, North Norfolk, England. Boreas 19(2):165-180

Hart JK, Watts RJ (1997) A comparison of the styles of deformation associated with two recent push moraines, south Van Keulenfjorden, Svalbard. Earth Surface Processes and Landforms 22:1089-1107

Hodgkins R, Hagen JO, Hamran SE (1999) 20th century mass balance and thermal regime change at Scott Turnerbreen, Svalbard. Annals of Glaciology 28(1):216-220

Huddart D, Hambrey MJ (1996) Sedimentary and tectonic development of a high-arctic, thrustmoraine complex: Comfortlessbreen, Svalbard. Boreas 25(4):227-243

Ingólfsson Ó, Benediktsson ÍÖ, Schomacker A, Kjær KH, Brynjólfsson S, Jónsson SA, Korsgaard NK, Johnson MD (2016) Glacial geological studies of surge-type glaciers in Iceland-Research status and future challenges. Earth-Science Reviews 152:37-69

James TD, Murray T, Barrand NE, Sykes HJ, Fox AJ, King MA (2012) Observations of enhanced thinning in the upper reaches of Svalbard glaciers. The Cryosphere 6(6):13691381

Jiskoot H, Boyle P, Murray T (1998) The incidence of glacier surging in Svalbard: evidence from multivariate statistics. Computers \& Geosciences 24(4):387-399

Jiskoot H, Murray T, Boyle P (2000) Controls on the distribution of surge-type glaciers in Svalbard. Journal of Glaciology 46(154):412-422

Kälin M (1971). The active push moraine of the Thompson Glacier, Axel Heiberg Island, Canadian Arctic Archipelago. Axel Heiberg Island Research Reports, Glaciology No. 4, McGill University, Montreal. PhD Thesis, ETH Zürich

Kehew AE, Beukema SP, Bird BC, Kozlowski AL (2005) Fast flow of the Lake Michigan Lobe: evidence from sediment-landform assemblages in southwestern Michigan, USA. Quaternary Science Reviews 24(22):2335-2353

King O, Hambrey MJ, Irvine-Fynn TD, Holt TO (2016) The structural, geometric and volumetric changes of a polythermal Arctic glacier during a surge cycle: Comfortlessbreen, Svalbard. Earth Surface Processes and Landforms 41(2):162-177

Kjær KH, Korsgaard NJ, Schomacker A (2008) Impact of multiple glacier surges - a geomorphological map from Brúarjökull, East Iceland. Journal of Maps 4(1):5-20 
Kristensen L, Benn DI, Hormes A, Ottesen D (2009a) Mud aprons in front of Svalbard surge moraines: Evidence of subglacial deforming layers or proglacial glaciotectonics? Geomorphology 111:206-221

Kristensen L, Juliussen H, Christiansen HH, Humlum O (2009b) Structure and composition of a tidewater glacier push moraine, Svalbard, revealed by DC resistivity profiling. Boreas 38:176-186

Lamplugh CW (1911) On the shelly moraine of the Sefström Glacier and other Spitsbergen phenomena illustrative of British glacial conditions. Proceedings of the Yorkshire Geological and Polytechnic Society 17(3):216-241

Larsen NK, Kronborg C, Yde JC, Knudsen NT (2010) Debris entrainment by basal freeze-on and thrusting during the 1995-1998 surge of Kuannersuit Glacier on Disko Island, west Greenland. Earth Surface Processes and Landforms 35(5):561-574

Lefauconnier B, Hagen JO (1991) Surging and calving glaciers in eastern Svalbard. Norwegian Polarinstitutt Meddeleler, pp 116

Liestø1 Ø 1993. Glaciers of Svalbard, Norway. US Geological Survey Professional Paper 1386:127-151

Lønne I (2016) A new concept for glacial geological investigations of surges, based on HighArctic examples (Svalbard). Quaternary Science Reviews 132:74-100

Lovell H, Stokes CR, Bentley MJ, Benn DI (2012) Evidence for rapid ice flow and proglacial lake evolution around the central Strait of Magellan region, southernmost Patagonia. Journal of Quaternary Science 27(6):625-638

Lovell H, Fleming EJ, Benn DI, Hubbard B, Lukas S, Rea BR, Noormets R, Flink AE (2015a) Debris entrainment and landform genesis during tidewater glacier surges. Journal of Geophysical Research: Earth Surface 120(8):1574-1595

Lovell H, Fleming EJ, Benn DI, Hubbard B, Lukas S, Naegeli K (2015b) Former dynamic behaviour of a cold-based valley glacier on Svalbard revealed by basal ice and structural glaciology investigations. Journal of Glaciology 61(226):309-328

Małecki J, Faucherre S, Strzelecki MC (2013) Post-surge geometry and thermal structure of Hørbyebreen, central Spitsbergen. Polish Polar Research 34:305-321

Małecki J (2016) Accelerating retreat and high-elevation thinning of glaciers in central Spitsbergen. The Cryosphere 10(3):1317-1329

Meier MF, Post A (1969) What are glacier surges? Canadian Journal of Earth Sciences 6(4):807-817 
Murray T, Strozzi T, Luckman A, Jiskoot H, Christakos P (2003) Is there a single surge mechanism? Contrasts in dynamics between glacier surges in Svalbard and other regions. Journal of Geophysical Research: Solid Earth 108(B5)

Nuth C, Kohler J, König M, Deschwanden AV, Hagen JO, Kääb A, Morholdt G, Pettersson R (2013) Decadal changes from a multi-temporal glacier inventory of Svalbard. The Cryosphere 7(5):1603-1621

Ottesen D, Dowdeswell JA (2006) Assemblages of submarine landforms produced by tidewater glaciers in Svalbard. Journal of Geophysical Research: Earth Surface 111(F1)

Rea BR, Evans DJA (2011) An assessment of surge-induced crevassing and the formation of crevasse squeeze ridges. Journal of Geophysical Research: Earth Surface 116(F4)

Roberts DH, Yde JC, Knudsen NT, Long AJ, Lloyd JM (2009) Ice marginal dynamics during surge activity, Kuannersuit Glacier, Disko Island, West Greenland. Quaternary Science Reviews 28:209-222

Schomacker A, Kjær KH (2008) Quantification of dead-ice melting in ice-cored moraines at the high-Arctic glacier Holmströmbreen, Svalbard. Boreas 37(2):211-225

Schomacker A, Benediktsson ÍÖ, Ingólfsson Ó (2014) The Eyjabakkajökull glacial landsystem, Iceland: geomorphic impact of multiple surges. Geomorphology 218:98-107

Sevestre H, Benn DI (2015) Climatic and geometric controls on the global distribution of surgetype glaciers: implications for a unifying model of surging. Journal of Glaciology 61 (228):646-662

Sharp M (1985) "Crevasse-fill" ridges: A landform type characteristic of surging glaciers? Geografiska Annaler. Series A. Physical Geography 67(3-4):213-220

Sletten K, Lyså A, Lønne I (2001) Formation and disintegration of a high-arctic ice-cored moraine complex, Scott Turnerbreen, Svalbard. Boreas 30(4):272-284

Streuff K, Forwick M, Szczuciński W, Andreassen K, Ó Cofaigh C (2015) Submarine landform assemblages and sedimentary processes related to glacier surging in Kongsfjorden, Svalbard. arktos 1(1):1-19

Sund M, Eiken T, Hagen JO, Kääb A (2009) Svalbard surge dynamics derived from geometric changes. Annals of Glaciology 50(52):50-60

van der Meer JJM (ed) (2004) Spitsbergen Push Moraines: Including a Translation of K. Gripp: Glaciologische und Geologische Ergebnisse Der Hamburgischen SpitzbergenExpedition 1927 (4). Elsevier, Amsterdam 
677

678

679

680

681

682

683

684

685

686

687

688

689

690

691

692

693

694

van der Wateren FM (1995) Structural geology and sedimentology of push moraines: processes of soft sediment deformation in a glacial environment and the distribution of glaciotectonic styles. Mededelingen Rijks Geologische, 54

von Heuglin MT (1872) Reise in Norwegen und Spitzbergen 1870, Braunschweig

Yde JC, Knudsen NT, Larsen NK, Kronborg C, Nielsen OB, Heinemeier J, Olsen J (2005) The presence of thrust-block naled after a major surge event: Kuannersuit Glacier, West Greenland. Annals of Glaciology 42(1):145-150

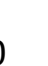

1

(1)

675

(1)

8

79

880

82

83

84

85

686

87

88


698 (1999) and Lønne (2016).

\begin{tabular}{|c|c|c|}
\hline Key feature & Description & Interpretation \\
\hline \multirow[t]{7}{*}{$\begin{array}{l}\text { Multi-ridged } \\
\text { sediment } \\
\text { accumulation }\end{array}$} & $\begin{array}{l}\text { Large, topographic sediment accumulation } \\
\text { ranging from } \sim 0.2-2 \mathrm{~km} \text {-wide (proximal to } \\
\text { distal flanks), } \sim 0.7-5 \mathrm{~km} \text {-long (lateral } \\
\text { extents) and } \sim 30-50 \mathrm{~m} \text { high (relative to } \\
\text { adjacent surfaces) (Fig. } 2 \text { ). Often arcuate in } \\
\text { planform (e.g. Figs } 2 \mathrm{f}-\mathrm{h} \text { ). }\end{array}$ & $\begin{array}{l}\text { - Significant shortening/compression of the } \\
\text { pre-surge foreland by proglacial deformation } \\
\text { during glacier advance results in folding and } \\
\text { stacking of sediments into defined ridges. }\end{array}$ \\
\hline & $\begin{array}{l}\text { - Series of multiple (>3) separate ridges } \\
\text { identifiable on surface of sediment } \\
\text { accumulation (Fig. 2). }\end{array}$ & $\begin{array}{l}\text { - Ridges are the surface expression of } \\
\text { glacitectonic deformation (e.g. folding and } \\
\text { emplacement of thrust slabs). }\end{array}$ \\
\hline & $\begin{array}{l}\text { Typically located in a proglacial latero- } \\
\text { frontal position (Fig. 2), but can be found in } \\
\text { lateral positions. }\end{array}$ & $\begin{array}{l}\text { - Formed by bulldozing/pushing of proglacial } \\
\text { sediments in front of an advancing glacier } \\
\text { margin. }\end{array}$ \\
\hline & $\begin{array}{l}\text { - Clear elevation difference between sediment } \\
\text { accumulation and surface of adjacent extra- } \\
\text { /proglacial area (e.g. Figs } 2 \mathrm{~b} \text { and } 2 \mathrm{e} \text { ). }\end{array}$ & $\begin{array}{l}\text { - Adjacent surfaces are at same relative height } \\
\text { as pre-surge foreland, therefore lower than } \\
\text { post-surge complex. }\end{array}$ \\
\hline & $\begin{array}{l}\text { - Clear elevation difference between sediment } \\
\text { accumulation and glacier surface (Fig. 2e). }\end{array}$ & $\begin{array}{l}\text { Formation in the proglacial zone means } \\
\text { no/little buried ice within the ridges or ice } \\
\text { that is continuous with the glacier, meaning } \\
\text { ridges and glacier can be separately defied } \\
\text { upon frontal recession. }\end{array}$ \\
\hline & $\begin{array}{l}\text { - Surface often has a smooth texture (e.g. Figs } \\
\text { 2b, 2e and } 2 \mathrm{f} \text { ) and in places retains } \\
\text { characteristics of the pre-tectonic sediment } \\
\text { surface (e.g. channel forms). }\end{array}$ & $\begin{array}{l}\text { - Reflects typical sorted and fine-grained } \\
\text { sediment composition (e.g. gravel, sand, silt, } \\
\text { clay) of the composite ridge system(and } \\
\text { therefore pre-surge foreland). }\end{array}$ \\
\hline & $\begin{array}{l}\text { - Slope instability indicators (e.g. debris } \\
\text { flows) are typically absent or minimal (Fig. } \\
\text { 2). }\end{array}$ & $\begin{array}{l}\text { No significant buried glacier ice in } \\
\text { complexes due to proglacial formation. }\end{array}$ \\
\hline \multirow[t]{4}{*}{$\begin{array}{l}\text { Ridges within } \\
\text { system }\end{array}$} & $\begin{array}{l}\text { Ridge crest alignment is typically } \\
\text { perpendicular to dominant ice flow direction } \\
\text { and crestlines are straight to slightly } \\
\text { curvilinear (i.e. not sinuous) (e.g. Fig. 2b). }\end{array}$ & $\begin{array}{l}\text { Bulldozing/pushing in front of advancing } \\
\text { glacier margin creates ridges oriented } \\
\text { transverse to glacier flow direction, but } \\
\text { which are not the result of fluvial erosion. }\end{array}$ \\
\hline & $\begin{array}{l}\text { Ridge morphology is typically rounded and, } \\
\text { across the whole complex, this creates an } \\
\text { undulating surface (e.g. Figs } 2 \mathrm{a} \text { and } 2 \mathrm{~b} \text { ). } \\
\text { Ridges are rarely discrete and sharp-crested. }\end{array}$ & $\begin{array}{l}\text { - Ridges are surface expression of } \\
\text { glacitectonic deformation (e.g. predominantly } \\
\text { folding and emplacement of thrust slabs) of } \\
\text { coherent sediment mass. }\end{array}$ \\
\hline & $\begin{array}{l}\text { Individual ridge width (distance between } \\
\text { lower breaks-of-slope) and spacing (crest-to- } \\
\text { crest) is typically } \sim 10-30 \mathrm{~m} \text {. Ridge width is } \\
\text { typically larger than spacing width (Fig. 2). }\end{array}$ & $\begin{array}{l}\text { Reflects proglacial glacitectonic origin as } \\
\text { opposed to ridges derived from englacial } \\
\text { debris structures (controlled) or fluvial } \\
\text { erosion. }\end{array}$ \\
\hline & $\begin{array}{l}\text { - In a latero-frontal and lateral position, the } \\
\text { ridges are not a continuation of the lateral } \\
\text { moraine (and linearity thereof) (e.g. Fig. 2h). }\end{array}$ & $\begin{array}{l}\text { Reflects proglacial glacitectonic origin as } \\
\text { opposed to ridges derived from englacial } \\
\text { debris structures (controlled) or fluvial } \\
\text { erosion. }\end{array}$ \\
\hline
\end{tabular}




\begin{tabular}{|l|l|l|}
\hline $\begin{array}{l}\text { Meltwater } \\
\text { channels }\end{array}$ & $\begin{array}{l}\text { Deep (up to 20 m) meltwater channels } \\
\text { form often sinuous canyons/gorges cut } \\
\text { (typically normal to crestlines) through } \\
\text { ridges within the complex (e.g. Figs 2b and } \\
\text { 2e-h). }\end{array}$ & $\begin{array}{l}\text { - } \\
\text { Channels represent syn-/post-tectonic } \\
\text { drainage originating from run-off points at } \\
\text { the ice margin and cutting-through the } \\
\text { complex. }\end{array}$ \\
\cline { 2 - 4 } & $\begin{array}{l}\text { Some channels terminate within the complex } \\
\text { and are truncated by ridges (e.g. Fig. 2e). }\end{array}$ & $\begin{array}{l}\text { Truncated channels could be the result of } \\
\text { different phases of deformation during } \\
\text { composite ridge systemformation and/or } \\
\text { multiple separate ridge-building advances } \\
\text { creating a piggy-backed moraine system. }\end{array}$ \\
\hline
\end{tabular}

699

700

701

702

703

704

705

706

707

708

709

710

711

712

713

714

715

716

717

718

719

720

721

722

723

724

725 
727 Table 2 Glaciers with composite ridge systems in Svalbard

\begin{tabular}{|c|c|c|c|c|c|c|c|c|}
\hline Glacier & Island & Region & Terminus & $\begin{array}{l}\text { Composite } \\
\text { ridge } \\
\text { system } \\
\text { Lat./Long. }\end{array}$ & $\begin{array}{l}\text { Documented } \\
\text { surge-type }^{c}\end{array}$ & $\begin{array}{l}\text { Creva } \\
\text { sse- } \\
\text { squee } \\
\text { ze } \\
\text { ridges } \\
\text { (CSR } \\
\text { ) }\end{array}$ & $\begin{array}{c}\text { Photograp } \\
\text { h year }\end{array}$ & $\begin{array}{c}\text { Key } \\
\text { reference }( \\
\text { s) for } \\
\text { composite } \\
\text { ridge } \\
\text { system }\end{array}$ \\
\hline $\begin{array}{c}\text { Abrahamse } \\
\text { nbreen }^{\text {ab }}\end{array}$ & Spitsbergen & NWS & Terrestrial & $\begin{array}{l}79.1846^{\circ} \mathrm{N} \\
14.5368^{\circ} \mathrm{E} \\
\end{array}$ & Yes & Yes & 2011 & $\begin{array}{l}\text { Lønne } \\
\text { (2016) }\end{array}$ \\
\hline $\begin{array}{c}\text { Arnesenbr } \\
\text { een }^{\mathrm{b}}\end{array}$ & Spitsbergen & SS & Marine & $\begin{array}{l}77.8716^{\circ} \mathrm{N} \\
18.3228^{\circ} \mathrm{E}\end{array}$ & Yes & Yes & 2012 & \\
\hline $\begin{array}{c}\text { Augnebree } \\
n\end{array}$ & Barents $\varnothing y a$ & BEØ & Marine & $\begin{array}{l}78.5705^{\circ} \mathrm{N}, \\
21.7948^{\circ} \mathrm{E}\end{array}$ & No & Yes & 2010 & \\
\hline $\begin{array}{c}\text { Austre } \\
\text { Kvitisen } \\
\end{array}$ & Edgeøуа & BEØ & Terrestrial & $\begin{array}{l}78.0476^{\circ} \mathrm{N}, \\
21.6969^{\circ} \mathrm{E}\end{array}$ & Yes & Yes & 2010 & \\
\hline $\begin{array}{c}\text { Battyebree } \\
n^{\text {ab }}\end{array}$ & Spitsbergen & NWS & Terrestrial & $\begin{array}{l}78.9388^{\circ} \mathrm{N} \\
15.2315^{\circ} \mathrm{E}\end{array}$ & Yes & Yes & 2011 & \\
\hline $\mathrm{BE} \varnothing-13^{\mathrm{d}}$ & Edgeøуа & $\mathrm{BE} \varnothing$ & Terrestrial & $\begin{array}{l}77.8307^{\circ} \mathrm{N}, \\
22.5578^{\circ} \mathrm{E}\end{array}$ & No & Yes & 2010 & \\
\hline $\begin{array}{c}\text { Besselsbre } \\
\text { en }\end{array}$ & Barents $\varnothing$ ya & BEØ & Marine & $\begin{array}{l}78.5657^{\circ} \mathrm{N}, \\
21.4213^{\circ} \mathrm{E}\end{array}$ & No & Yes & 2011 & \\
\hline $\begin{array}{l}\text { Comfortles } \\
\text { sbreen }^{\mathrm{b}}\end{array}$ & Spitsbergen & NWS & Marine & $\begin{array}{c}78.8385^{\circ} \mathrm{N} \\
11.9044^{\circ} \mathrm{E}\end{array}$ & Yes & Yes & 2009 & $\begin{array}{l}\text { Huddart } \\
\text { and } \\
\text { Hambrey } \\
\text { (1996); } \\
\text { King et al. } \\
\text { (2016); } \\
\text { Lønne } \\
\text { (2016) }\end{array}$ \\
\hline$\underset{b}{\text { Deltabreen }}$ & Edgeøya & BEØ & Marine & $\begin{array}{l}77.5122^{\circ} \mathrm{N}, \\
22.9913^{\circ} \mathrm{E}\end{array}$ & Yes & Yes & 2010 & \\
\hline $\begin{array}{c}\text { Duckwitzb } \\
\text { reen }\end{array}$ & Barents $\varnothing$ ya & $\mathrm{BE} \varnothing$ & Marine & $\begin{array}{l}78.3142^{\circ} \mathrm{N}, \\
20.7318^{\circ} \mathrm{E}\end{array}$ & Yes & Yes & 2010 & $\begin{array}{l}\text { Gripp } \\
\text { (1929) }\end{array}$ \\
\hline $\begin{array}{c}\text { Edvardbre } \\
\mathrm{en}^{\mathrm{b}}\end{array}$ & Spitsbergen & SS & Terrestrial & $\begin{array}{l}77.9690^{\circ} \mathrm{N}, \\
17.5754^{\circ} \mathrm{E}\end{array}$ & Yes & Yes & 2011 & $\begin{array}{l}\text { Lønne } \\
(2016)\end{array}$ \\
\hline $\begin{array}{c}\text { Elfenbeinb } \\
\text { reen }^{\text {ab }}\end{array}$ & Spitsbergen & CS & Terrestrial & $\begin{array}{c}78.1156^{\circ} \mathrm{N}, \\
18.1521^{\circ} \mathrm{E}\end{array}$ & Yes & $\mathrm{No}^{\mathrm{e}}$ & 1936 & $\begin{array}{l}\text { Gripp } \\
\text { (1929) }\end{array}$ \\
\hline Erikbreen $^{\mathrm{b}}$ & Spitsbergen & NWS & $\begin{array}{c}\text { Terrestrial } \\
\text { (lake) }\end{array}$ & $\begin{array}{l}79.5904^{\circ} \mathrm{N} \\
12.6001^{\circ} \mathrm{E}\end{array}$ & No & Yes & 2011 & \\
\hline $\begin{array}{l}\text { Finsterwal } \\
\text { derbreen }^{\text {ab }}\end{array}$ & Spitsbergen & SS & Terrestrial & $\begin{array}{l}77.5322^{\circ} \mathrm{N} \\
15.3265^{\circ} \mathrm{E}\end{array}$ & Yes & Yes & 2011 & $\begin{array}{c}\text { Hart and } \\
\text { Watts } \\
\text { (1997); } \\
\text { Lønne } \\
\text { (2016) }\end{array}$ \\
\hline $\begin{array}{c}\text { Gandbreen } \\
\mathrm{b}\end{array}$ & Edgeøya & BEØ & $\begin{array}{c}\text { Terrestrial } \\
\text { (lake) }\end{array}$ & $\begin{array}{l}77.7085^{\circ} \mathrm{N}, \\
22.7388^{\circ} \mathrm{E}\end{array}$ & No & Yes & 2010 & \\
\hline $\begin{array}{c}\text { Gardebree } \\
\mathrm{n}\end{array}$ & Spitsbergen & NES & Terrestrial & $\begin{array}{l}78.5884^{\circ} \mathrm{N}, \\
19.5157^{\circ} \mathrm{E}\end{array}$ & No & Yes & 2011 & \\
\hline $\begin{array}{c}\text { Grønfjordb } \\
\text { reen }\end{array}$ & Spitsbergen & CS & $\begin{array}{c}\begin{array}{c}\text { Terrestrial } \\
\text { (lake) }\end{array} \\
\end{array}$ & $\begin{array}{l}77.9602^{\circ} \mathrm{N}, \\
14.3292^{\circ} \mathrm{E}\end{array}$ & Yes & No & 2004 & $\begin{array}{l}\text { Gripp } \\
\text { (1929) }\end{array}$ \\
\hline $\begin{array}{c}\text { Gullfakseb } \\
\text { reen }\end{array}$ & Spitsbergen & NES & Terrestrial & $\begin{array}{l}79.5837^{\circ} \mathrm{N}, \\
17.5534^{\circ} \mathrm{E}\end{array}$ & No & Yes & 2010 & \\
\hline $\begin{array}{c}\text { Holms tröm } \\
\text { breen }^{\text {ab }}\end{array}$ & Spitsbergen & NWS & $\begin{array}{c}\text { Terrestrial } \\
\text { (lake) }\end{array}$ & $\begin{array}{l}78.7784^{\circ} \mathrm{N}, \\
14.5509^{\circ} \mathrm{E}\end{array}$ & Yes & Yes & 2009 & $\begin{array}{l}\text { Boulton et } \\
\text { al. (1999) }\end{array}$ \\
\hline $\begin{array}{l}\text { Inglefieldb } \\
\text { reen }^{\text {ab }}\end{array}$ & Spitsbergen & SS & Marine & $\begin{array}{l}77.9199^{\circ} \mathrm{N} \\
18.2054^{\circ} \mathrm{E}\end{array}$ & Yes & Yes & 2012 & \\
\hline
\end{tabular}




\begin{tabular}{|c|c|c|c|c|c|c|c|c|}
\hline $\begin{array}{c}\text { Karlsbreen } \\
a b\end{array}$ & Spitsbergen & NWS & $\begin{array}{c}\text { Terrestrial } \\
\text { (lake) }\end{array}$ & $\begin{array}{l}79.3827^{\circ} \mathrm{N}, \\
13.4487^{\circ} \mathrm{E}\end{array}$ & Yes & No & 2011 & \\
\hline $\begin{array}{l}\text { Koristkabr } \\
\text { een }\end{array}$ & Spitsbergen & NES & Marine & $\begin{array}{l}78.8472^{\circ} \mathrm{N}, \\
21.2097^{\circ} \mathrm{E}\end{array}$ & No & Yes & 2011 & \\
\hline $\begin{array}{c}\text { Kosterbree } \\
n\end{array}$ & Spitsbergen & NES & Marine & $\begin{array}{l}79.3019^{\circ} \mathrm{N}, \\
18.8206^{\circ} \mathrm{E}\end{array}$ & Yes & Yes & 2010 & \\
\hline$\underset{b}{\text { Kuhrbreen }}$ & Edgeøya & ВEØ & Terrestrial & $\begin{array}{l}77.5011^{\circ} \mathrm{N}, \\
21.7686^{\circ} \mathrm{E}\end{array}$ & Yes & Yes & 2010 & $\begin{array}{l}\text { Lønne } \\
(2016)\end{array}$ \\
\hline Kvastbreen & Spitsbergen & $\mathrm{SS}$ & Marine & $\begin{array}{l}77.4203^{\circ} \mathrm{N}, \\
17.5553^{\circ} \mathrm{E}\end{array}$ & Yes & Yes & 2011 & \\
\hline $\begin{array}{c}\text { Laubefjelle } \\
\text { breen }\end{array}$ & Spitsbergen & NES & Marine & $\begin{array}{l}78.8495^{\circ} \mathrm{N}, \\
21.1432^{\circ} \mathrm{E}\end{array}$ & No & Yes & 2011 & \\
\hline $\begin{array}{c}\text { Lisbetbree } \\
\mathrm{n}^{\mathrm{ab}}\end{array}$ & Spitsbergen & NWS & Terrestrial & $\begin{array}{l}79.0401^{\circ} \mathrm{N}, \\
15.4848^{\circ} \mathrm{E}\end{array}$ & Yes & Yes & 2011 & \\
\hline $\begin{array}{c}\text { Mittag- } \\
\text { Lefflerbree } \\
n \\
\end{array}$ & Spitsbergen & NES & Marine & $\begin{array}{l}78.9166^{\circ} \mathrm{N}, \\
16.5029^{\circ} \mathrm{E}\end{array}$ & Yes & Yes & 2011 & \\
\hline $\begin{array}{c}\text { Nathorstbr } \\
\text { een }^{\text {a }}\end{array}$ & Spitsbergen & SS & Marine & $\begin{array}{l}77.5291^{\circ} \mathrm{N}, \\
16.0599^{\circ} \mathrm{E}\end{array}$ & Yes & Yes & 2011 & $\begin{array}{l}\text { Gripp } \\
(1929)\end{array}$ \\
\hline Paulabreen & Spitsbergen & SS & Marine & $\begin{array}{l}77.8658^{\circ} \mathrm{N}, \\
16.5484^{\circ} \mathrm{E}\end{array}$ & Yes & Yes & 2011 & $\begin{array}{l}\text { Kristensen } \\
\text { et al. } \\
(2009 a, b)\end{array}$ \\
\hline $\begin{array}{c}\text { Penckbree } \\
n^{\text {ab }}\end{array}$ & Spitsbergen & SS & $\begin{array}{c}\text { Terrestrial } \\
\text { (lake) }\end{array}$ & $\begin{array}{l}77.5223^{\circ} \mathrm{N} \\
15.5906^{\circ} \mathrm{E}\end{array}$ & Yes & Yes & 2011 & $\begin{array}{l}\text { Hart and } \\
\text { Watts } \\
\text { (1997); } \\
\text { Lønne } \\
\text { (2016) }\end{array}$ \\
\hline $\begin{array}{c}\text { Rabotbree } \\
n^{\text {ab }}\end{array}$ & Spitsbergen & $\mathrm{CS}$ & Terrestrial & $\begin{array}{l}78.2711^{\circ} \mathrm{N}, \\
17.8996^{\circ} \mathrm{E}\end{array}$ & No & Yes & 2012 & \\
\hline $\begin{array}{l}\text { Reymondb } \\
\text { reen }^{b}\end{array}$ & Barents $\emptyset$ ya & $\mathrm{BE} \varnothing$ & Terrestrial & $\begin{array}{l}78.4043^{\circ} \mathrm{N}, \\
22.1578^{\circ} \mathrm{E}\end{array}$ & Yes & Yes & 2010 & \\
\hline $\begin{array}{l}\text { Schweigaa } \\
\text { rdbreen }\end{array}$ & $\begin{array}{c}\text { Nordaustlan } \\
\text { det }\end{array}$ & NA & Marine & $\begin{array}{l}80.2400^{\circ} \mathrm{N}, \\
24.7657^{\circ} \mathrm{E}\end{array}$ & No & No & 2011 & \\
\hline $\begin{array}{l}\text { Schwerdtb } \\
\text { reen }^{b}\end{array}$ & Edgeøуа & BEØ & Terrestrial & $\begin{array}{l}77.7295^{\circ} \mathrm{N}, \\
21.7085^{\circ} \mathrm{E}\end{array}$ & No & Yes & 2010 & \\
\hline $\begin{array}{c}\text { Sefströmbr } \\
\text { een }^{\text {ab }}\end{array}$ & Spitsbergen & NWS & Marine & $\begin{array}{l}78.6738^{\circ} \mathrm{N}, \\
14.7176^{\circ} \mathrm{E}\end{array}$ & Yes & Yes & 2009 & $\begin{array}{l}\text { Boulton et } \\
\text { al. (1996) }\end{array}$ \\
\hline Seidbreen $^{b}$ & Edgeøуа & BEØ & $\begin{array}{c}\text { Terrestrial } \\
\text { (lake) }\end{array}$ & $\begin{array}{l}77.7598^{\circ} \mathrm{N}, \\
22.7149^{\circ} \mathrm{E}\end{array}$ & No & Yes & 2010 & \\
\hline $\begin{array}{c}\text { Skrentbree } \\
n^{\mathrm{b}}\end{array}$ & Edgeøуа & $\mathrm{BE} \varnothing$ & Terrestrial & $\begin{array}{l}77.5073^{\circ} \mathrm{N}, \\
21.5921^{\circ} \mathrm{E}\end{array}$ & Yes & No & 2010 & $\begin{array}{l}\text { Lønne } \\
(2016)\end{array}$ \\
\hline $\begin{array}{c}\text { Stubendorf } \\
\text { fbreen }^{\mathrm{b}}\end{array}$ & Spitsbergen & NES & Marine & $\begin{array}{l}78.9798^{\circ} \mathrm{N}, \\
16.4165^{\circ} \mathrm{E}\end{array}$ & No & Yes & 2011 & \\
\hline $\begin{array}{c}\text { Supanbree } \\
n^{\mathrm{b}}\end{array}$ & Spitsbergen & NWS & Terrestrial & $\begin{array}{l}79.3008^{\circ} \mathrm{N}, \\
11.8298^{\circ} \mathrm{E}\end{array}$ & Yes & No & 2009 & \\
\hline Ulvebreen & Spitsbergen & $\mathrm{CS}$ & Marine & $\begin{array}{l}78.1978^{\circ} \mathrm{N}, \\
18.9982^{\circ} \mathrm{E}\end{array}$ & Yes & Yes & 2012 & $\begin{array}{l}\text { Gripp } \\
\text { (1929) }\end{array}$ \\
\hline $\begin{array}{c}\text { Usherbree } \\
n^{a b}\end{array}$ & Spitsbergen & $\mathrm{CS}$ & Terrestrial & $\begin{array}{c}78.2640^{\circ} \mathrm{N} \\
18.9264^{\circ} \mathrm{E}\end{array}$ & Yes & Yes & 2012 & $\begin{array}{l}\text { Hagen } \\
\text { (1988); } \\
\text { Lønne } \\
\text { (2016) }\end{array}$ \\
\hline $\begin{array}{c}\text { Uvêrsbree } \\
n^{b}\end{array}$ & Spitsbergen & NWS & Terrestrial & $\begin{array}{c}78.8347^{\circ} \mathrm{N} \\
12.0841^{\circ} \mathrm{E}\end{array}$ & Yes & Yes & 2009 & $\begin{array}{c}\text { Hambrey } \\
\text { and } \\
\text { Huddart } \\
\text { (1995) }\end{array}$ \\
\hline $\begin{array}{c}\text { Veidebree } \\
n^{\mathrm{b}}\end{array}$ & Edgeøуa & BEØ & Terrestrial & $\begin{array}{l}77.6639^{\circ} \mathrm{N}, \\
22.4641^{\circ} \mathrm{E}\end{array}$ & No & Yes & 2010 & \\
\hline
\end{tabular}




\begin{tabular}{|c|c|c|c|c|c|c|c|}
\hline $\begin{array}{c}\text { Vestre } \\
\text { Edgeøyjøk } \\
\text { ulen }^{b}\end{array}$ & Edgeøуа & BEØ & Terrestrial & $\begin{array}{l}77.8460^{\circ} \mathrm{N}, \\
22.6334^{\circ} \mathrm{E}\end{array}$ & No & Yes & 2010 \\
\hline $\begin{array}{c}\text { Vestre } \\
\text { Torellbree } \\
n^{b}\end{array}$ & Spitsbergen & SS & Marine & $\begin{array}{l}77.1977^{\circ} \mathrm{N}, \\
14.4728^{\circ} \mathrm{E}\end{array}$ & No & Yes & 2011 \\
\hline Veteranen $^{b}$ & Spitsbergen & NES & Terrestrial & $\begin{array}{l}79.3700^{\circ} \mathrm{N}, \\
17.5745^{\circ} \mathrm{E}\end{array}$ & Yes & No & 2010 \\
\hline $\begin{array}{c}\text { Vetternbre } \\
\text { en }^{\mathrm{b}}\end{array}$ & Spitsbergen & NWS & $\begin{array}{c}\text { Terrestrial } \\
\text { (lake) }\end{array}$ & $\begin{array}{l}78.2767^{\circ} \mathrm{N}, \\
13.3031^{\circ} \mathrm{E}\end{array}$ & No & Yes & 2009 \\
\hline Vonbreen $^{\mathrm{ab}}$ & Spitsbergen & NWS & $\begin{array}{l}\text { Terrestrial } \\
\text { (lake) }\end{array}$ & $\begin{array}{l}79.2615^{\circ} \mathrm{N}, \\
13.9393^{\circ} \mathrm{E}\end{array}$ & No & Yes & 2011 \\
\hline $\begin{array}{l}\text { Winsnesbr } \\
\text { een }\end{array}$ & $\begin{array}{c}\text { Nordaustlan } \\
\text { det }\end{array}$ & NA & Terrestrial & $\begin{array}{l}79.7880^{\circ} \mathrm{N}, \\
22.1263^{\circ} \mathrm{E}\end{array}$ & No & Yes & 2011 \\
\hline
\end{tabular}


753 Table 3 Number of total glaciers, glaciers $>1 \mathrm{~km}^{2}$ (both from Hagen et al. (1993)), documented 754 surge-type glaciers (according to Croot (1988a) and Farnsworth et al. (2016; and references 755 therein)), glaciers with crevasse-squeeze ridge (CSR) networks (according to Farnsworth et al., 756 2016) and glaciers with composite ridge systems as distributed by region (see Fig. 5). NWS = 757 northwest Spitsbergen, NES = northeast Spitsbergen, CS = central Spitsbergen, SS = south 758 Spitsbergen, $\mathrm{NA}=$ Nordaustlandet, $\mathrm{BE} \varnothing=$ Barents $\varnothing \mathrm{ya}$ and Edgeøya. Percentages are out of 759 the total glacier population in each region, apart from those marked by $*$ that are calculated 760 relative to the total glacier population in Svalbard

\begin{tabular}{|c|c|c|c|c|c|c|c|c|c|c|c|c|c|c|}
\hline \multirow{2}{*}{ Regions } & \multicolumn{2}{|c|}{ NWS } & \multicolumn{2}{|c|}{ NES } & \multicolumn{2}{|c|}{ CS } & \multicolumn{2}{|c|}{ SS } & \multicolumn{2}{|c|}{ NA } & \multicolumn{2}{|c|}{ ВЕФ } & \multicolumn{2}{|c|}{ Svalbard } \\
\hline & $n$ & $\%$ & $n$ & $\%$ & $n$ & $\%$ & $n$ & $\%$ & $n$ & $\%$ & $n$ & $\%$ & $n$ & $\%$ \\
\hline All glaciers & 704 & $\begin{array}{c}32.2 \\
*\end{array}$ & 201 & $9.2^{*}$ & 403 & $\begin{array}{c}18.5 \\
*\end{array}$ & 316 & $\begin{array}{c}14.5 \\
*\end{array}$ & 214 & $9.8^{*}$ & 345 & $\begin{array}{c}15.8 \\
*\end{array}$ & 2183 & - \\
\hline $\begin{array}{c}\text { Glaciers }>1 \\
\mathrm{~km}^{2}\end{array}$ & 374 & 53.1 & 117 & 58.2 & 193 & 47.9 & 145 & 45.9 & 78 & 36.4 & 112 & 32.5 & 1019 & 46.7 \\
\hline $\begin{array}{c}\text { Surge-type } \\
\text { glaciers }\end{array}$ & 78 & 11.1 & 23 & 11.4 & 43 & 10.7 & 111 & 35.1 & 11 & 5.1 & 14 & 4.1 & 280 & 12.8 \\
\hline CSR networks & 225 & 32.0 & 71 & 35.3 & 60 & 14.9 & 199 & 63.0 & 3 & 1.4 & 54 & 15.7 & 612 & 28.0 \\
\hline $\begin{array}{l}\text { Composite } \\
\text { ridge systems }\end{array}$ & 12 & 1.7 & 8 & 4.0 & 5 & 1.2 & 9 & 2.8 & 2 & 0.9 & 14 & 4.1 & 50 & 2.3 \\
\hline $\begin{array}{c}\text { Surge-type } \\
\text { glaciers plus } \\
\text { previously } \\
\text { undocumented } \\
\text { surges }^{\text {a }}\end{array}$ & 241 & 34.2 & 78 & 38.8 & 83 & 20.6 & 239 & 75.6 & 14 & 6.5 & 56 & 16.2 & 711 & 32.6 \\
\hline
\end{tabular}
their margins (CSR networks and composite ridge systems) but have not been observed to surge/documented as surge-type 
795

796

797

798

799

800

801

802

803

804

805

Fig. 1 Location map of Svalbard showing distribution of composite ridge systems according to Croot (1988a) (white dots) and this study (black squares; listed in Table 2). Regions: NWS $=$ Northwest Spitsbergen; NES $=$ Northeast Spitsbergen; CS $=$ Central Spitsbergen; SS = South Spitsbergen; BE $\varnothing=$ Barentsøya and Edgeøya; NA = Nordaustlandet.

Fig. 2 Examples of composite ridge systems as identified from aerial photographs. (a) Abrahamsenbreen; (b) Battyebreen; (c) Erikbreen; (d) Finsterwalderbreen; (e) Gandbreen; (f) Kuhrbreen (right) and Skrentbreen (left); (g) Penckbreen; (h) Usherbreen. Red arrows indicate generalised flow direction of the glaciers. See online version for figure in colour

Fig. 3 Examples of controlled moraines (cf. Evans, 2009) and fluvially-dissected moraine/ice-marginal sediment masses that could be misidentified as composite ridge systems. Controlled moraines at (a) Andreasbreen $\left(78.6142^{\circ} \mathrm{N}, 12.1783^{\circ} \mathrm{E}\right)$ and (b) Greinbreane $\left(77.9195^{\circ} \mathrm{N}, 16.0522^{\circ} \mathrm{E}\right)$. Fluvially-dissected moraine/sediment masses at (c) Elnabreen $\left(79.1919^{\circ} \mathrm{N}, 14.0367^{\circ} \mathrm{E}\right)$ and (d) Instebreen $\left(77.6566^{\circ} \mathrm{N}, 15.2470^{\circ} \mathrm{E}\right)$. Of these, (c) is listed as a composite ridge system in Croot (1988a) and all are listed as push moraines in Hagen et al. (1993). Red arrow indicates generalised flow direction of the glacier. Small back arrows in (b) highlight evidence for de-icing in the form of debris flows. See online version for figure in colour

Fig. 4 Examples of previously unreported composite ridge systems in Svalbard. (a) Augnebreen; (b) Gardebreen; (c) Koristkabreen; (d) Laubefjellebreen; (e) MittagLefflerbreen; (f) Schweigaardbreen. Red arrow indicates generalised flow direction of the glacier. See online version for figure in colour

Fig. 5 Map showing distributions by region and numbers of: all glaciers, glaciers with an area $>1 \mathrm{~km}^{2}$ (both based on Hagen et al. (1993)), documented surge-type glaciers (according to Croot (1988a) and Farnsworth et al. (2016; and references therein)), glaciers with reported crevasse-squeeze ridge networks (according to Farnsworth et al. (2016)) and glaciers with composite ridge systems (this study). Regions: NWS $=$ Northwest Spitsbergen; NES = Northeast Spitsbergen; CS = Central Spitsbergen; SS = South 

version for figure in colour

808 


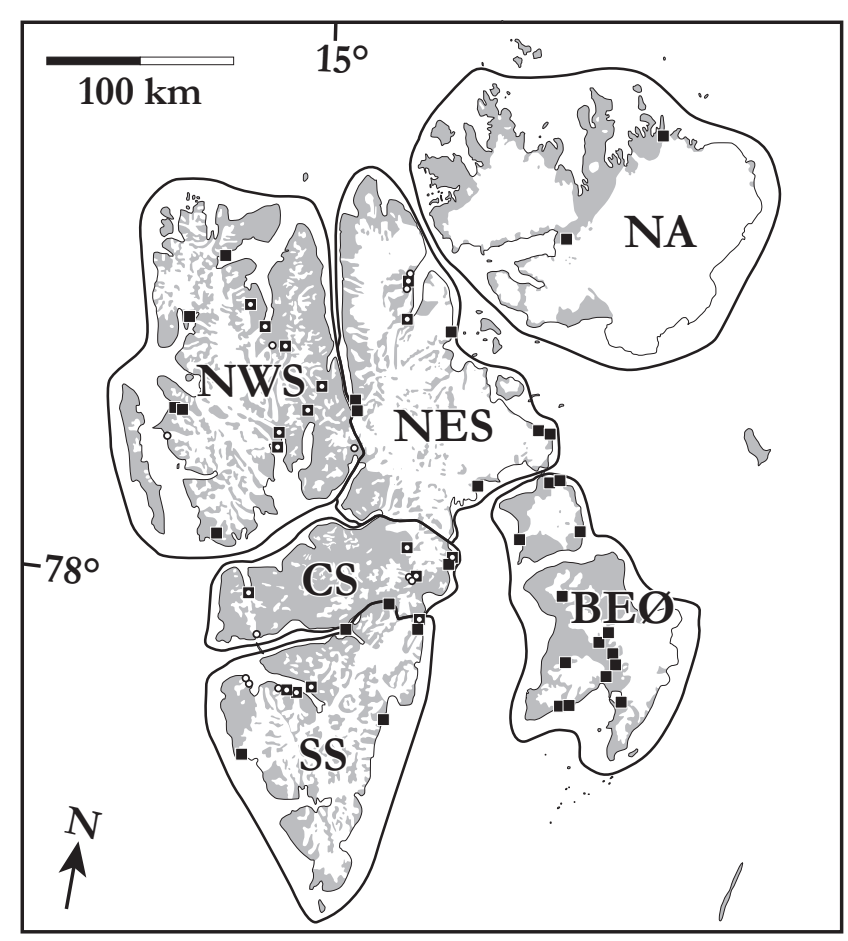

Fig. 1 

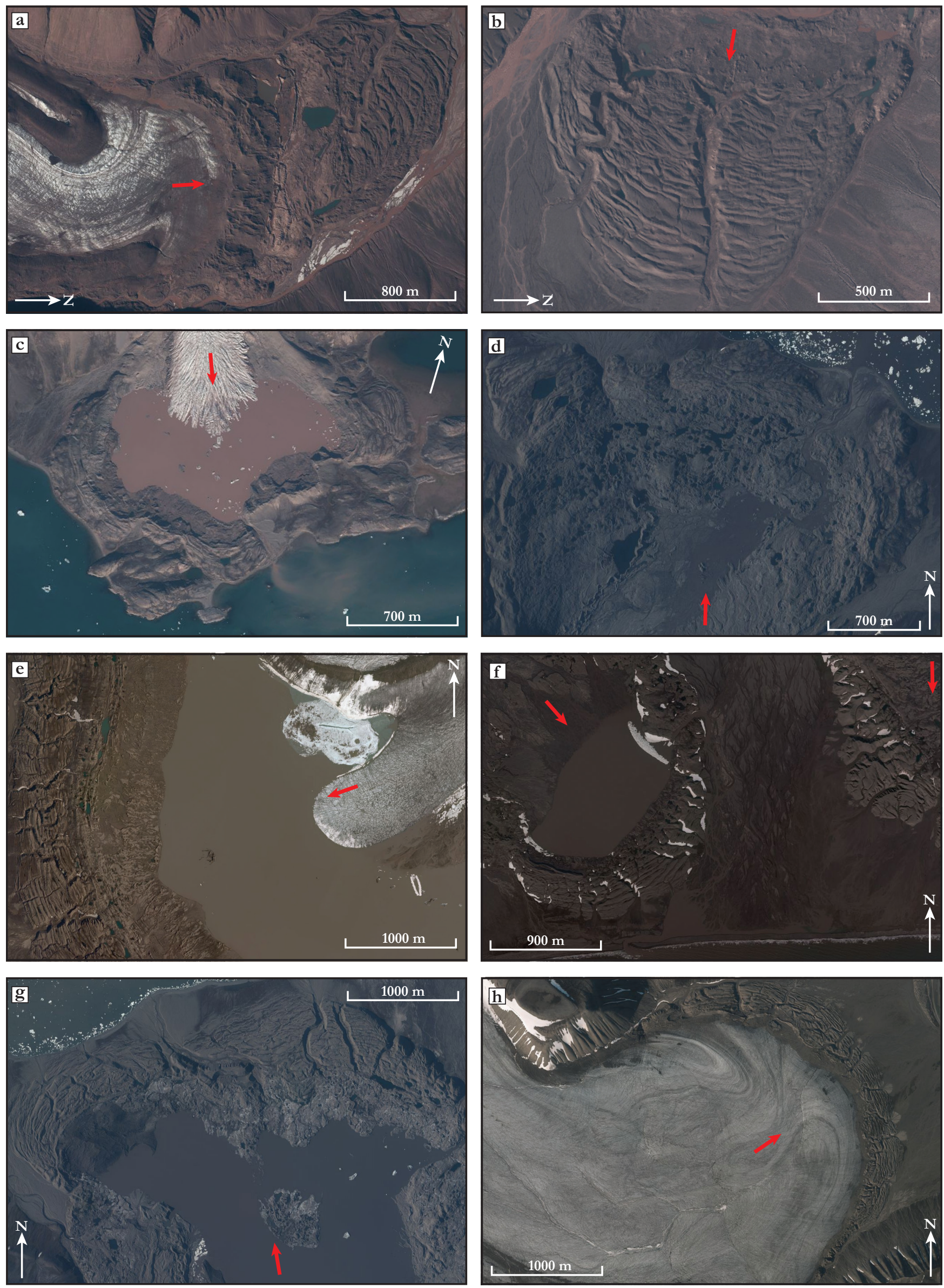

Fig. 2 

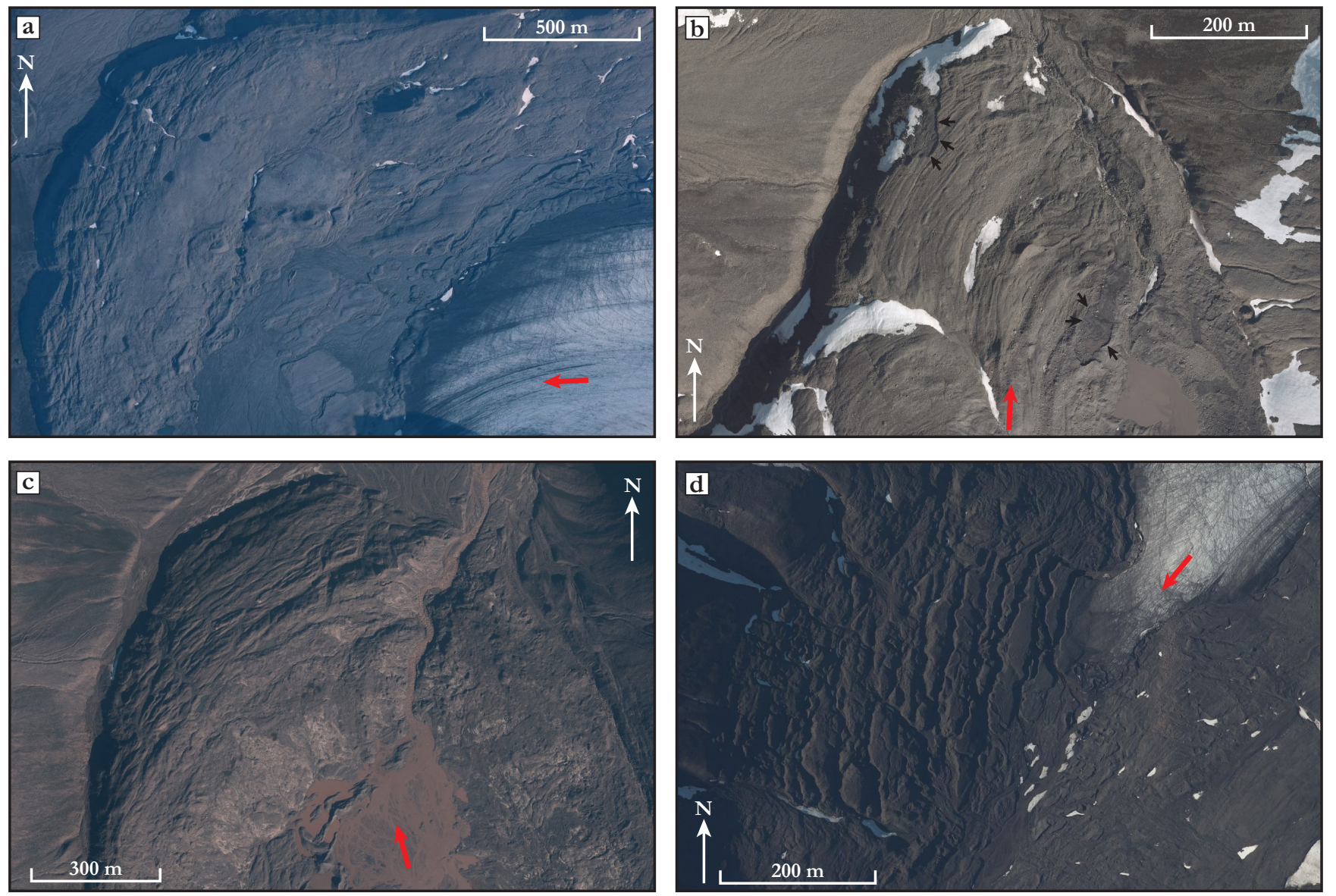

Fig. 3 

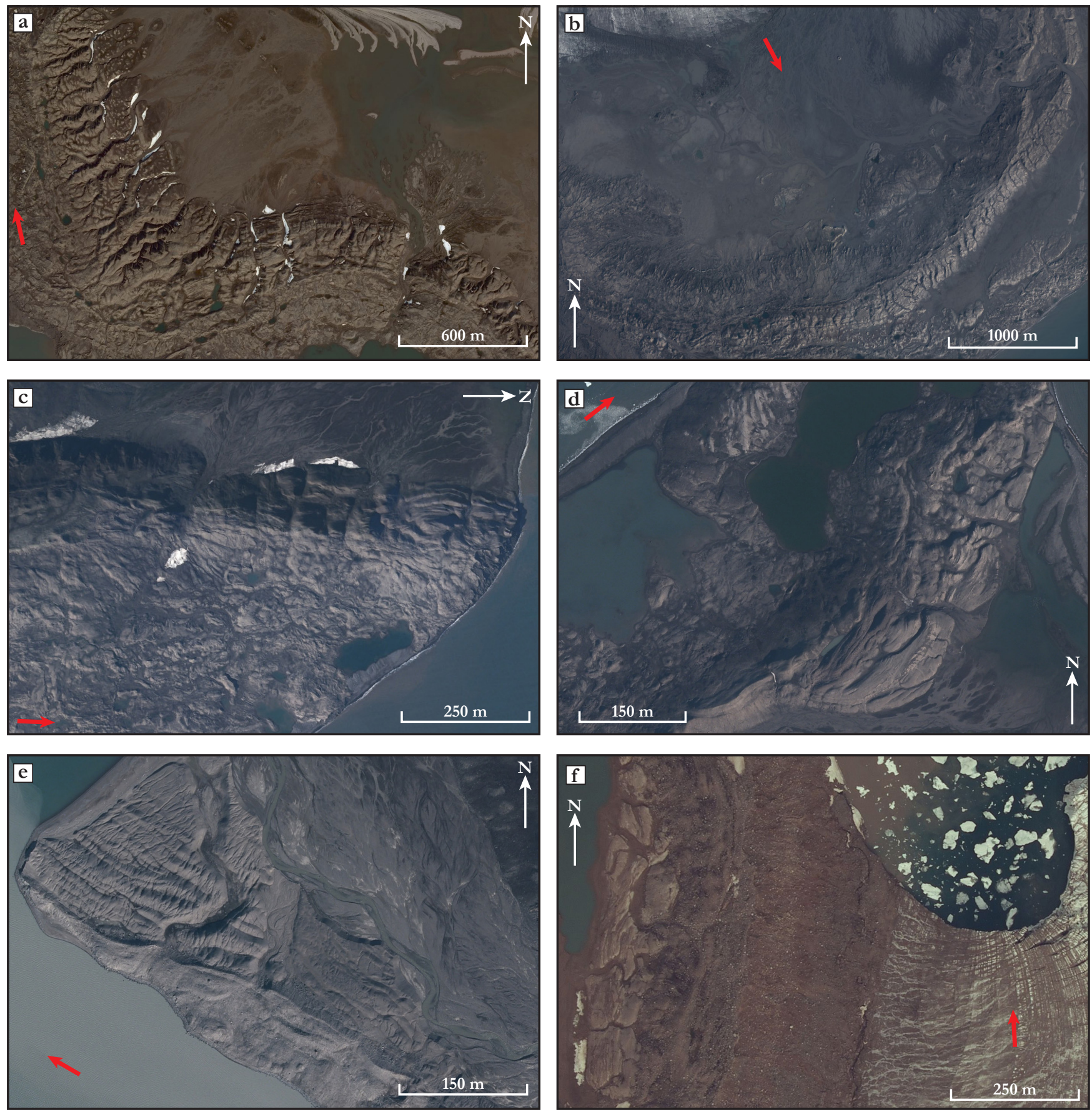

Fig. 4 


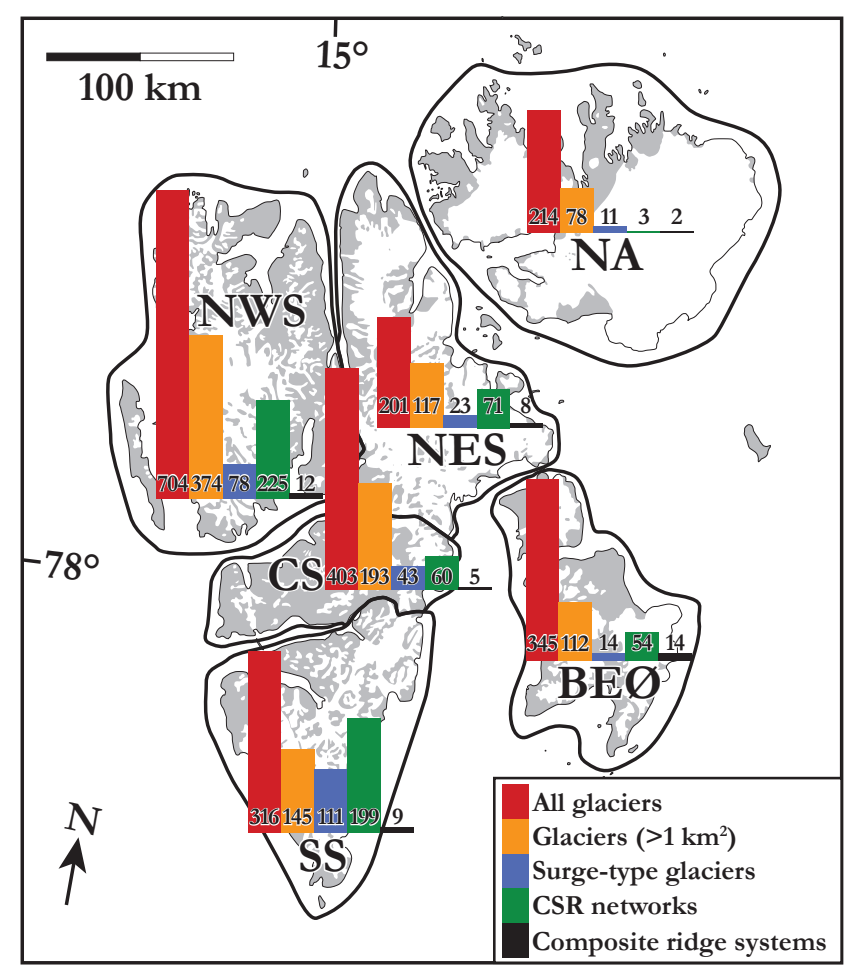

Fig. 5 